\title{
Sodium Hypochlorite: Effect of Solution pH on Rice Seed Disinfestation and Its Direct Effect on Seedling Growth
}

\author{
S.-C. Chun, R. W. Schneider, and M. A. Cohn, Department of Plant Pathology and Crop Physiology, Louisiana \\ State University Agricultural Center, Baton Rouge 70803
}

\begin{abstract}
Chun, S.-C., Schneider, R. W., and Cohn, M. A. 1997. Sodium hypochlorite: Effect of solution $\mathrm{pH}$ on rice seed disinfestation and its direct effect on seedling growth. Plant Dis. 81:821-824.

Bacteria were completely eliminated from rice seeds following immersion in household bleach solutions $(50 \%$ bleach and $2.6 \% \mathrm{NaOCl}$ ) adjusted to $\mathrm{pH} 7.0$ in $0.5 \mathrm{M}$ potassium phosphate, while fungi were eliminated at $\mathrm{pH} 5.0$ and below. Mercuric chloride was used to disinfest nondormant rice seeds in order to test the direct effect of sodium hypochlorite on rice seedling growth apart from an indirect effect related to elimination of microbial contaminants. Seeds were immersed for $2 \mathrm{~h}$ in each solution or water in each of the following treatments: (i) sterile water followed by sterile water, (ii) $\mathrm{HgCl}_{2}\left(1,000 \mu \mathrm{g} / \mathrm{ml}\right.$ ) followed by sterile water, (iii) $\mathrm{HgCl}_{2}$ followed by $\mathrm{KH}_{2} \mathrm{PO}_{4}\left(0.3 \mathrm{M}\right.$ ), (iv) $\mathrm{HgCl}_{2}$ followed by $\mathrm{NaOCl}$, and (v) $\mathrm{NaOCl}$ followed by sterile water. Sodium hypochlorite solutions were prepared in $0.3 \mathrm{M}$ potassium phosphate, which gave a final $\mathrm{pH}$ of 7.3. Seedling growth in treatments in which seeds were treated with $\mathrm{HgCl}_{2}$ followed by $\mathrm{NaOCl}$, and $\mathrm{NaOCl}$ followed by sterile water, was significantly greater than those treatments in which seeds were treated with sterile water followed by sterile water, $\mathrm{HgCl}_{2}$ followed by sterile water, and $\mathrm{HgCl}_{2}$ followed by $\mathrm{KH}_{2} \mathrm{PO}_{4}$. Sodium hypochlorite stimulated rice seedling growth directly, as opposed to an indirect effect related to elimination of microbial contaminants or alleviation of dormancy.
\end{abstract}

Additional keywords: biological control, seed pathology, surface-sterilization

Household bleach, composed of $5.25 \%$ sodium hypochlorite $(\mathrm{NaOCl})$ and $4 \%$ $\mathrm{NaCl}, \mathrm{pH}$ about 11.4 (R. Tam, The Clorox Company, personal communication), is routinely used as a seed disinfestant in studies involving seedborne pathogens, biological control, endophytes, and seed germination, as well as in commercial applications (16,21-23). When using bleach in this manner, the implied assumption is that any effects subsequent to surface disinfestation are related to the experimental treatment, e.g., biological control agent, and there is no direct effect of hypochlorite on seedling growth.

The objective of this research was to determine the influence of sodium hypochlorite on rice (Oryza sativa L.) seedling growth apart from that attributed to disinfestation. Mercuric chloride and Vitavax 200FF (17.5\% carboxin and $17.5 \%$ thiram; Gustafson, McKinney, TX) were included as additional seed disinfestation agents for comparative purposes in some experiments. A companion study was conducted to determine the relationship between $\mathrm{pH}$ of hy-

Corresponding author: R. W. Schneider E-mail: RSCHNEI@UNIX1.SNCC.LSU.EDU

Accepted for publication 8 April 1997.

Publication no. D-1997-0509-05R

(C) 1997 The American Phytopathological Society pochlorite solutions and efficacy of seed disinfestation. A preliminary report was published (4).

\section{MATERIALS AND METHODS}

The effect of $\mathrm{pH}$ of sodium hypochlorite solutions on disinfestation of rice seeds. A range of initial $\mathrm{pH}$ values of $50 \%$ household bleach $(2.6 \% \mathrm{NaOCl})$ solutions (The Clorox Company, Oakland, CA) was established with various buffers including phosphoric acid ( $\mathrm{pH} 2)$, potassium phosphate ( $\mathrm{pH} 3$ to 7$)$, and Tris- $\mathrm{HCl}(\mathrm{pH} 8$ to 9). Buffered bleach solutions below $\mathrm{pH} 7.0$ were prepared in an exhaust hood, because chlorine and $\mathrm{HOCl}$ are products of the chemical reactions (1). Final concentration of buffers was $0.5 \mathrm{M}$, which was required to prevent changes in solution $\mathrm{pH}$ during the experiments. Unbuffered bleach was diluted $1: 1(\mathrm{vol} / \mathrm{vol})$ with distilled water, which gave a final $\mathrm{pH}$ of 11.6. Sterile buffered water ( $\mathrm{pH} 7.1,1.0 \mathrm{mM}$ phosphate) was used as the control. Ten grams of rice seeds (cv. Lemont) was soaked in $100 \mathrm{ml}$ of freshly prepared solutions contained in 150-ml beakers for $2 \mathrm{~h}$ at room temperature. The beakers were sealed with laboratory film (Parafilm 'M'; American National Can, Greenwich, CT) and agitated three times during the soak. The seeds were then rinsed, with agitation, in four changes of $150 \mathrm{ml}$ of sterile distilled water. The seeds were removed from the final rinse and incubated on nutrient agar (NA) at $32^{\circ} \mathrm{C}$ and on acidified $(\mathrm{pH} 3.0)$ potato dextrose agar (APDA) at $28^{\circ} \mathrm{C}$ for assessment of bacterial and fungal contamination, respectively. After 3 days of incubation, the numbers of seeds contaminated with bacteria and fungi and the number of germinated seeds on APDA were determined. In a preliminary experiment, the germinability of rice seeds was reduced on NA plates if there was a high rate of bacterial contamination. There were five replications (petri dishes) per treatment with 20 seeds per replication, and the experiment was conducted twice.

Efficacy of disinfestation with mercuric chloride and Vitavax $200 \mathrm{FF}$ as compared with household bleach. Ten grams of nondormant rice seeds was soaked for 2 $\mathrm{h}$ at room temperature in $100 \mathrm{ml}$ of freshly prepared buffered $(\mathrm{pH} 7.3)$ bleach solution $(2.6 \% \mathrm{NaOCl})$ as described above, by diluting household bleach with $0.6 \mathrm{M}$ phosphate buffer $(1: 1, \mathrm{vol} / \mathrm{vol})$ and in $\mathrm{HgCl}_{2}$ solutions prepared in distilled water and adjusted to $500,1,000,2,000,3,000,4,000$, and $5,000 \mu \mathrm{g} / \mathrm{ml}(1.85,3.69,7.38,11.07$, 14.76 , and $18.45 \mathrm{mM}$, respectively). An unbuffered bleach solution prepared with distilled water and sterile distilled water treatments also were included. Seeds were then rinsed four times with sterile distilled water as described above. A separate treatment was included in which seeds were treated with Vitavax 200FF $(2.5 \mathrm{ml} / \mathrm{kg}$ of seed) (25) as another means of reducing fungal contamination. Seeds were assessed for bacterial and fungal contamination as described above. There were five replications (petri dishes) per treatment with 20 seeds per replication, and the experiment was conducted twice.

Effect of sodium hypochlorite on rice seedling growth. We attempted to separate the possible direct effect of hypochlorite on seedling growth from an indirect effect related to disinfestation. These two effects were separated by first disinfesting seeds with $1,000 \mu \mathrm{g} / \mathrm{ml}(3.69 \mathrm{mM})$ of $\mathrm{HgCl}_{2}$ followed by treatment with $\mathrm{NaOCl}$. In addition, Vitavax 200FF was used as another seed disinfestant. Seeds were immersed for $2 \mathrm{~h}$ in each of two solutions (or water) in the following treatments: (i) sterile distilled water followed by sterile distilled water, (ii) seeds treated with Vitavax 200FF (2.5 $\mathrm{ml} / \mathrm{kg}$ of seeds) soaked in sterile distilled water for $4 \mathrm{~h}$, (iii) $\mathrm{HgCl}_{2}$ followed by sterile distilled water, (iv) $\mathrm{HgCl}_{2}$ followed by $\mathrm{KH}_{2} \mathrm{PO}_{4}(0.3 \mathrm{M})$, (v) $\mathrm{HgCl}_{2}$ followed 
by $2 \% \mathrm{NaCl}$, (vi) $\mathrm{HgCl}_{2}$ followed by $\mathrm{NaOCl}(2.6 \%$ for bleach and 2 to $3 \%$ for reagent-grade $\mathrm{NaOCl}$ ), and (vii) $\mathrm{NaOCl}$ (2.6\% for bleach and 2 to $3 \%$ for reagentgrade $\mathrm{NaOCl}$ ) followed by sterile distilled water. Mercuric chloride followed by $2 \%$ $\mathrm{NaCl}$ was included to test the effect of $\mathrm{NaCl}$ on seedling growth, because commercial bleach (Clorox) contains $4 \% \mathrm{NaCl}$. Sodium hypochlorite solutions were pre-

Table 1. Influence of $\mathrm{pH}$ of household bleach solutions on bacterial and fungal contamination of rice seeds and seed germination

\begin{tabular}{lccc}
\hline & \multicolumn{2}{c}{$\begin{array}{c}\text { Percent } \\
\text { contamination with }\end{array}$} & $\begin{array}{c}\text { Percent } \\
\text { pH }\end{array}$ \\
\cline { 2 - 3 } & Bacteria & Fungi & germination \\
\hline 2 & $0 \mathrm{a}^{\mathrm{x}}$ & $3 \mathrm{a}$ & $89 \mathrm{c}$ \\
3 & $0 \mathrm{a}$ & $0 \mathrm{a}$ & $42 \mathrm{a}$ \\
4 & $0 \mathrm{a}$ & $0 \mathrm{a}$ & $78 \mathrm{~b}$ \\
5 & $0 \mathrm{a}$ & $0 \mathrm{a}$ & $82 \mathrm{~b}$ \\
6 & $0 \mathrm{a}$ & $9 \mathrm{a}$ & $89 \mathrm{c}$ \\
7 & $0 \mathrm{a}$ & $22 \mathrm{~b}$ & $95 \mathrm{~cd}$ \\
8 & $100 \mathrm{c}$ & $79 \mathrm{~d}$ & $95 \mathrm{~cd}$ \\
9 & $100 \mathrm{c}$ & $39 \mathrm{c}$ & $96 \mathrm{~cd}$ \\
Unbuffered $^{\mathrm{w}}$ & $30 \mathrm{~b}$ & $39 \mathrm{c}$ & $100 \mathrm{~d}$ \\
Control $^{\mathrm{z}}$ & $100 \mathrm{c}$ & $96 \mathrm{e}$ & $97 \mathrm{~cd}$ \\
\hline
\end{tabular}

${ }^{w}$ The $\mathrm{pH}$ of household bleach solutions was adjusted with (1:1, vol/vol) $1.0 \mathrm{M}$ phosphoric acid $(\mathrm{pH} 2), 1.0 \mathrm{M}$ potassium phosphate $(\mathrm{pH} 3$ to 7), and 1.0 M Tris- $\mathrm{HCl}$ ( $\mathrm{pH} 8$ to 9).

${ }^{x}$ Means followed by the same letters within columns are not significantly different (StudentNewman-Keuls test, $P=0.05$ ) (24). Statistical analyses were conducted following arcsine transformation of percent contamination (24).

${ }^{\mathrm{y}} \mathrm{pH}$ of unbuffered bleach was about 11.6.

${ }^{\mathrm{z}}$ Sterile buffered water.

Table 2. Efficacy of surface-sterilization of rice seeds with different chemical treatments

\begin{tabular}{|c|c|c|}
\hline \multirow[b]{2}{*}{ Treatments } & \multicolumn{2}{|c|}{$\begin{array}{l}\text { Percent of seeds } \\
\text { contaminated with }\end{array}$} \\
\hline & Bacteria & Fungi \\
\hline Control $^{\mathrm{u}}$ & $98 \mathrm{e}^{\mathrm{v}}$ & $100 \mathrm{f}$ \\
\hline Vitavax $200 \mathrm{FF}^{\mathrm{w}}$ & $85 \mathrm{~d}$ & $18 \mathrm{ab}$ \\
\hline $\mathrm{HgCl}_{2}(500)^{\mathrm{x}}$ & $21 \mathrm{~b}$ & $45 \mathrm{~d}$ \\
\hline $\mathrm{HgCl}_{2}(1,000)$ & $9 \mathrm{a}$ & $45 \mathrm{~d}$ \\
\hline $\mathrm{HgCl}_{2}(2,000)$ & $9 \mathrm{a}$ & $40 \mathrm{~d}$ \\
\hline $\mathrm{HgCl}_{2}(3,000)$ & $3 a$ & $27 \mathrm{c}$ \\
\hline $\mathrm{HgCl}_{2}(4,000)$ & $2 \mathrm{a}$ & $25 \mathrm{bc}$ \\
\hline $\mathrm{HgCl}_{2}(5,000)$ & $2 \mathrm{a}$ & $13 \mathrm{a}$ \\
\hline $\begin{array}{l}\text { Household bleach } \\
(\mathrm{pH} 11.6)^{\mathrm{y}}\end{array}$ & $41 \mathrm{c}$ & $61 \mathrm{e}$ \\
\hline $\begin{array}{l}\text { Household bleach } \\
(\mathrm{pH} 7.3)^{\mathrm{z}}\end{array}$ & $3 a$ & $43 \mathrm{~d}$ \\
\hline
\end{tabular}

u Sterile distilled water.

$\checkmark$ Values followed by the same letters within columns are not significantly different (StudentNewman-Keuls test, $P=0.05$ ). Statistical analyses were conducted following arcsine transformation of percent contamination (24).

${ }^{\mathrm{w}}$ Composed of $17.5 \%$ carboxin and $17.5 \%$ thiram (25). Treated seeds were soaked in sterile distilled water for $2 \mathrm{~h}$.

${ }^{x}$ Numbers in parentheses are the concentrations of mercuric chloride $(\mu \mathrm{g} / \mathrm{ml})$.

y $50 \%$ household bleach $(2.6 \% \mathrm{NaOCl})$ in distilled water.

${ }^{\mathrm{z}} \mathrm{pH}$ of household bleach was adjusted (1:1, vol/ vol) with $0.6 \mathrm{M}$ potassium phosphate buffer. pared by diluting (1:1, vol/vol) household bleach or reagent-grade $\mathrm{NaOCl}$ with $0.6 \mathrm{M}$ potassium phosphate, which gave a final $\mathrm{pH}$ of 7.3. After treatment, seeds were planted in sterilized, covered glass storage dishes that contained $50 \mathrm{~cm}^{3}$ of sterile soil and $100 \mathrm{ml}$ of sterile buffered water $(\mathrm{pH} \mathrm{7.1}$, $1.0 \mathrm{mM}$ phosphate). They were incubated in a growth chamber at $30 / 30^{\circ} \mathrm{C}$ (day/ night) with 12 -h photoperiods for 10 days, at which time the lengths and dry weights of shoots and roots were measured. There were four replications per treatment, 25 plants per replication, and the experiment was conducted twice.

\section{RESULTS AND DISCUSSION}

Bacteria were completely eliminated from rice seeds following immersion in bleach solutions $(50 \%$ bleach and $2.6 \%$ $\mathrm{NaOCl}$ in $0.5 \mathrm{M}$ potassium phosphate) at or below $\mathrm{pH} 7.0$, while fungi were eliminated most effectively at pH 5.0 and below (Table 1). Buffer solutions without $\mathrm{NaOCl}$ did not affect levels of seed infestation (data not shown). Compared with higher $\mathrm{pH}$ values, seed germination was significantly lower at $\mathrm{pH} 3$ to 5 (Table 1), but was not affected at $\mathrm{pH} 2$. This may have been a response to a lower concentration of $\mathrm{HOCl}$ at $\mathrm{pH} 2.0$ relative to higher $\mathrm{pH}$ values (1). Brazis et al. (2) reported that the bactericidal activity of $\mathrm{HOCl}$ is about 100 -fold greater than $\mathrm{OCl}^{-}$, and this may explain why solution $\mathrm{pH}$ has such a marked effect. As $\mathrm{pH}$ declines from 10.0 to 5.0 in a solution with a given concentration of $\mathrm{NaOCl}$, the concentration of $\mathrm{HOCl}$ increases, while that of $\mathrm{OCl}^{-}$decreases. As $\mathrm{pH}$ declines from 5.0 to 1.0 , the concentration of $\mathrm{HOCl}$ declines, while that of $\mathrm{Cl}_{2}$ increases (1). Mercuric chloride at $1,000 \mu \mathrm{g} / \mathrm{ml}$ resulted in about the same level of disinfestation as bleach at pH 7.3 (Table 2). The fungicide treatment significantly reduced fungal contamination, but bacterial contamination was relatively unaffected (Table 2 ).

The $\mathrm{pH}$ of $50 \%$ household bleach prepared in distilled water $(2.6 \% \mathrm{NaOCl})$ was about 11.6. Our results showed that buffering the $\mathrm{pH}$ of bleach solutions to 7.0 significantly increased the efficacy of disinfestation. Efficacy of disinfestion with bleach solutions is dependent upon $\mathrm{NaOCl}$ concentration, $\mathrm{pH}$, water quality, storage condition, and age of the solution $(1,10)$. These variables often are not considered or fully documented, which may account for inconsistent results in the literature $(1,8)$.

The antimicrobial properties of hypochlorite solutions are affected by an equilibrium between the chlorine compounds present $(1,2)$. When hypochlorite is dissolved in water, it produces $\mathrm{HOCl}$, and $\mathrm{HOCl}$ dissociates reversibly into $\mathrm{H}^{+}$and $\mathrm{OCl}^{-}$with the final equilibrium dependent upon solution $\mathrm{pH}(1,2,10)$. Disinfestation with hypochlorite is best achieved at about $\mathrm{pH} 5$ and increases with higher temperature $(1,22,23)$, but the stability of hypochlorite solutions decreases under these conditions $(1,10)$. Recently, Robbs et al. (21) showed that initial oxidation-reduction potential of hypochlorite, which was higher at $\mathrm{pH} 6.0$ than at $\mathrm{pH} 8.0$, was correlated with the toxicity of chlorine solutions to Erwinia carotovora subsp. carotovora and conidia of Geotrichum candidum.

Because the efficacy of seed disinfestation of $\mathrm{HgCl}_{2}$ solutions equal to or greater than $1,000 \mu \mathrm{g} / \mathrm{ml}$ was similar to a $50 \%$ bleach solution at $\mathrm{pH} 7.3$, and the solutions were not phytotoxic, $\mathrm{HgCl}_{2}$ was used as a control for testing the effect of $\mathrm{NaOCl}$ on rice seedling growth apart from that attributed to seed disinfestation. The only nonhypochlorite treatments that had statistically positive effects, relative to the water-water control, were $\mathrm{HgCl}_{2}$-water and $\mathrm{HgCl}_{2}-\mathrm{NaCl}$ on root dry weight (Table 3 ). It is possible that $\mathrm{HgCl}_{2}$ eliminated seedborne contaminants that reduced root growth. These results suggest that roots and shoots responded differently to hypochlorite, with shoot growth being more responsive. We cannot rule out the possibility that $\mathrm{NaCl}$ had a beneficial effect on root dry weight in these experiments. However, when the experiment was

Table 3. Effect of household bleach and other sterilants on rice seedling growth

\begin{tabular}{lcccc}
\hline Treatments & $\begin{array}{c}\text { Shoot length } \\
(\mathbf{c m})\end{array}$ & $\begin{array}{c}\text { Root length } \\
(\mathbf{c m})\end{array}$ & $\begin{array}{c}\text { Shoot dry weight } \\
(\mathbf{m g})\end{array}$ & $\begin{array}{c}\text { Root dry weight } \\
(\mathbf{m g})\end{array}$ \\
\hline Water-water $^{\mathrm{t}}$ & $5.0 \mathrm{a}$ & $3.5 \mathrm{a}$ & $2.3 \mathrm{a}$ & $1.2 \mathrm{a}$ \\
Vitavax 200FF" & $4.1 \mathrm{a}$ & $3.9 \mathrm{a}$ & $2.1 \mathrm{a}$ & $1.4 \mathrm{a}$ \\
$\mathrm{HgCl}_{2}$-water & $5.0 \mathrm{a}$ & $5.0 \mathrm{ab}$ & $3.0 \mathrm{a}$ & $2.8 \mathrm{~b}$ \\
$\mathrm{HgCl}_{2}-\mathrm{KH}_{2} \mathrm{PO}_{4}{ }^{\mathrm{x}}$ & $4.9 \mathrm{a}$ & $4.6 \mathrm{ab}$ & $2.8 \mathrm{a}$ & $1.8 \mathrm{a}$ \\
$\mathrm{HgCl}_{2}-\mathrm{NaCl}^{\mathrm{y}}$ & $5.3 \mathrm{a}$ & $5.0 \mathrm{ab}$ & $2.9 \mathrm{a}$ & $3.1 \mathrm{c}$ \\
$\mathrm{HgCl}_{2}$-bleach & $6.8 \mathrm{~b}$ & $5.7 \mathrm{~b}$ & $4.1 \mathrm{~b}$ & $3.2 \mathrm{c}$ \\
Bleach-water $^{\mathrm{z}}$ & $7.0 \mathrm{~b}$ & $7.1 \mathrm{c}$ & $4.2 \mathrm{~b}$ & $3.2 \mathrm{c}$ \\
\hline
\end{tabular}

$\mathrm{s}$ Seeds were soaked for $2 \mathrm{~h}$ in the first solution and then $2 \mathrm{~h}$ in the second solution.

${ }^{\mathrm{t}}$ Control (sterile distilled water).

u Values followed by the same letters within columns are not significantly different (Student-Newman-Keuls test, $P=0.05)(24)$.

v Composed of $17.5 \%$ carboxin and $17.5 \%$ thiram (25). Treated seeds were soaked in sterile distilled water for $4 \mathrm{~h}$

${ }^{\text {w }}$ Concentration of $\mathrm{HgCl}_{2}$ was $1,000 \mu \mathrm{g} / \mathrm{ml}(3.69 \mathrm{mM})$.

${ }^{x}$ Final concentration $=0.3 \mathrm{M} \mathrm{KH}_{2} \mathrm{PO}_{4}$.

y $2 \% \mathrm{NaCl}$.

${ }^{\mathrm{z}}$ Household bleach was diluted (1:1, vol/vol) with $0.6 \mathrm{M}$ potassium phosphate, final pH 7.3. 
repeated with reagent-grade $\mathrm{NaOCl}$, the direct stimulatory effect was unambiguous. Except for root length in the $\mathrm{HgCl}_{2}$-water treatment, plant growth parameters were significantly greater in all reagent-grade $\mathrm{NaOCl}$ treatments (Table 4).

Aside from the antimicrobial properties of hypochlorite, we present evidence that hypochlorite acts directly to stimulate rice seedling growth. Seedling growth was significantly greater after seed treatment with $\mathrm{HgCl}_{2}$ followed by $\mathrm{NaOCl}(\mathrm{pH}$ 7.3). This effect was not related to disinfestation, phosphate, or $\mathrm{NaCl}$, in that the treatments that included $\mathrm{HgCl}_{2}$-water, $\mathrm{HgCl}_{2}-\mathrm{KH}_{2} \mathrm{PO}_{4}$, or $\mathrm{HgCl}_{2}-\mathrm{NaCl}$ did not result in increased seedling growth. Our observations of the plants suggest that hypochlorite promoted growth by stimulating the development of primary leaves after emergence of the coleoptile. In related studies, Hall (9) reported that treatment of sweet potatoes (Ipomoea batatas) with calcium hypochlorite reduced the time interval from bedding to first plant harvest. Fieldhouse and Sasser (5) reported that residual sodium hypochlorite significantly increased the rate of emergence of pepper seedlings (Capsicum annuum) and dry weight of the aboveground portions of plants. When sodium hypochlorite-treated seeds were acid-rinsed, there were no significant differences between the acid-rinsed $\mathrm{NaOCl}$ treatment and nontreated control (5). However, Cantliffe and Watkins (3) reported that $\mathrm{NaOCl}$ reduced the rate of pepper seed germination, but total percent germination was not affected. These contrasting results may have been caused by procedural differences. The former and latter authors used the same concentrations of $\mathrm{NaOCl}(1 \%$ available chlorine), but soaked their seeds for 5 and $40 \mathrm{~min}$, respectively.

Sodium hypochlorite has been used to break seed dormancy in several plant species including wild oat (Avena fatua), green needlegrass (Stipa viridula), wild buckwheat (Polygonum convolvulus), cow cockle (Saponaria vaccaria), Bouteloua curtipendula, and root parasites such as Aeginetia indica and Alectra vogeli $(6,7,11-15,18)$. The promotion of rice seedling growth by hypochlorite reported here is not related to the alleviation of seed dormancy in that seed germination in nonhypochlorite treatments was essentially $100 \%$ (Table 1). Furthermore, it is commonly known that rice seeds from short maturing varieties do not require a dormant period $(17,19,20)$. Mikkelsen and Sinah (17) reported that dilute solutions of $\mathrm{NaOCl}$ enhanced seedling growth, and they suggested that a germination inhibitor was inactivated in the rice seed hull, although direct evidence was not presented. We saw no evidence for such an effect in an experiment in which rate and percent germination of rice seeds at $30^{\circ} \mathrm{C}$ were measured following treatments with $\mathrm{NaOCl}$ and water. Less than 2 days were required for $50 \%$ germination in both treatments, and final germination was $97 \%$.

A precipitous decline in populations of biocontrol bacteria was observed when bacteria were inoculated onto rice seeds previously treated with bleach solutions adjusted to $\mathrm{pH} 7.0$ and rinsed several times with distilled water (R. W. Schneider, unpublished data). This was not the case when unbuffered bleach solutions were used. Apparently, distilled water rinses do not remove all the hypochlorite from seeds treated with buffered bleach. Also, toxic concentrations of chlorinated amines may have been produced on the seeds (1). However, residual hypochlorite can be removed by soaking seeds in $0.01 \mathrm{~N} \mathrm{HCl}$ without reducing germinability (1). Investigators conducting experiments in which seeds are surface-sterilized are cautioned to take into account the direct effect of sodium hypochlorite on seedling growth. Unless appropriate controls are included, spurious results may be obtained in studies involving plant growth regulators or biological control agents applied to seeds. Hypochlorite solutions should be acidified in a fume hood, because gaseous $\mathrm{HOCl}$ and $\mathrm{Cl}_{2}$ are produced.

\section{ACKNOWLEDGMENTS}

Approved for publication by the Director of the Louisiana Agricultural Experiment Station as manuscript 96-38-0160. Supported, in part, by USDA/NRI grant 94-37312-0626.

Table 4. Effect of reagent-grade sodium hypochlorite and mercuric chloride on rice seedling growth

\begin{tabular}{lcccc}
\hline Treatments $^{\mathbf{u}}$ & $\begin{array}{c}\text { Shoot length } \\
(\mathbf{c m})\end{array}$ & $\begin{array}{c}\text { Root length } \\
(\mathbf{c m})\end{array}$ & $\begin{array}{c}\text { Shoot dry weight } \\
(\mathbf{m g})\end{array}$ & $\begin{array}{c}\text { Root dry weight } \\
(\mathbf{m g})\end{array}$ \\
\hline Water-water $^{\mathrm{v}}$ & $5.4 \mathrm{a}^{\mathrm{w}}$ & $4.0 \mathrm{a}$ & $2.2 \mathrm{a}$ & $1.4 \mathrm{a}$ \\
$\mathrm{HgCl}_{2}-\mathrm{water}^{\mathrm{x}}$ & $5.7 \mathrm{a}$ & $4.9 \mathrm{bc}$ & $2.9 \mathrm{a}$ & $2.2 \mathrm{a}$ \\
$\mathrm{HgCl}_{2}-\mathrm{HgCl}_{2}{ }^{\mathrm{x}}$ & $5.5 \mathrm{a}$ & $4.2 \mathrm{a}$ & $2.8 \mathrm{a}$ & $2.2 \mathrm{a}$ \\
$\mathrm{HgCl}_{2}-\mathrm{KH}_{2} \mathrm{PO}_{4}{ }^{\mathrm{y}}$ & $5.3 \mathrm{a}$ & $4.1 \mathrm{a}$ & $2.4 \mathrm{a}$ & $1.7 \mathrm{a}$ \\
$\mathrm{HgCl}_{2}-\mathrm{NaOCl}^{\mathrm{z}}$ & $7.1 \mathrm{~b}$ & $6.1 \mathrm{~cd}$ & $3.8 \mathrm{~b}$ & $3.2 \mathrm{~b}$ \\
$\mathrm{NaOCl}^{-}$-ater $^{\mathrm{z}}$ & $7.8 \mathrm{~b}$ & $6.6 \mathrm{~d}$ & $3.7 \mathrm{~b}$ & $3.2 \mathrm{~b}$ \\
\hline
\end{tabular}

" Seeds were soaked for $2 \mathrm{~h}$ in the first solution and then $2 \mathrm{~h}$ in the second solution.

${ }^{v}$ Control (sterile distilled water).

${ }^{w}$ Means followed by same letters within columns are not significantly different (Student-Newman-

Keuls test, $P=0.05$ ) (24).

${ }^{x}$ Concentration of $\mathrm{HgCl}_{2}$ was $1,000 \mu \mathrm{g} / \mathrm{ml}(3.69 \mathrm{mM})$.

${ }^{\mathrm{y}}$ Final concentration $=0.3 \mathrm{M} \mathrm{KH}_{2} \mathrm{PO}_{4}$.

z 4 to $6 \%$ reagent-grade $\mathrm{NaOCl}$ was diluted $(1: 1, \mathrm{vol} / \mathrm{vol})$ with $0.6 \mathrm{M}$ potassium phosphate, final $\mathrm{pH} 7.3$.

\section{LITERATURE CITED}

1. Abdul-Baki, A. A., and Moore, G. M. 1979 Seed disinfection with hypochlorite: A selected literature review of hypochlorite. J. Seed Technol. 4:43-56.

2. Brazis, A. R., Leslie, J. P., Kabler, P. W., and Woodward, R. L. 1958. The inactivation of spores of Bacillus anthracis by free available chlorine. Appl. Microbiol. 6:338-342.

3. Cantliffe, D. J., and Watkins, J. T. 1983. More rapid germination of pepper seeds after seed treatment. Proc. Fla. State Hortic. Soc. 96:99101.

4. Chun, S.-C., and Schneider, R. W. 1993. The effect of $\mathrm{pH}$ of household bleach solutions used as a surface sterilant for rice seed. (Abstr.) Phytopathology 84:775.

5. Fieldhouse, D. J., and Sasser, M. 1975. Stimulation of pepper seed germination by sodium hypochlorite treatment. HortScience 10:622.

6. Frank, A. B., and Larson, K. L. 1970. Influence of oxygen, sodium hypochlorite, and dehulling on germination of green needlegrass seed (Stipa viridula Trin.). Crop Sci. 10:679682.

7. French, R. C., and Sherman, L. J. 1976. Factors affecting dormancy and seedling development of Aeginetia indica L. (Orobanchaceae). Am. J. Bot. 63:558-570.

8. Guthrie, J. W. 1978. Standardizing the use of sodium hypochlorite as a seed pretreatment. Assoc. Off. Seed Anal. Newsl. 52:41-49.

9. Hall, M. R. 1985. Influence of calcium hypochlorite and genotype on plant production by bedded sweet potato roots. HortScience 20: 692-693.

10. Hoffman, P. N., Death, J. E., and Coates, D. 1981. The stability of sodium hypochlorite solutions. Soc. Appl. Bacteriol. Technol. Ser. 16:77-83.

11. Hsiao, A. I. 1979. The effect of sodium hypochlorite and gibberellic acid on seed dormancy and germination of wild oats (Avena fatua). Can. J. Bot. 57:1729-1734.

12. Hsiao, A. I. 1979. The effect of sodium hypochlorite, gibberellic acid, and light on seed dormancy and germination of wild buckwheat (Polygonum convolvulus) and cow cockle (Saponaria vaccaria). Can. J. Bot. 57:17351739.

13. Hsiao, A. I., and Hanes, J. A. 1981. Application of the sodium hypochlorite seed viability test to wild oat populations with different dormancy characteristics. Can. J. Plant Sci. 61: 115-122.

14. Hsiao, A. I., and Quick, W. A. 1984. Actions of sodium hypochlorite and hydrogen peroxide on seed dormancy and germination of wild oats, Avena fatua L. Weed Res. 24:411-419.

15. Major, R. L., and Wright, L. N. 1974. Seed dormancy characteristics of sideoats gramagrass (Bouteloua curtipendula (Michx.) Torr.). Crop Sci. 14:37-40.

16. McInroy, J. A., and Kloepper, J. W. 1995. Population dynamics of endophytic bacteria in field-grown sweet corn and cotton. Can. J. Microbiol. 41:895-901.

17. Mikkelsen, D. S., and Sinah, M. N. 1961 Germination inhibition in Oryza sativa and control by preplanting soaking treatments. Crop Sci. 1:332-335.

18. Okonkwo, S. N. C., and Nwoke, F. I. O. 1975. Bleach-induced germination and breakage of dormancy of Alectra vogelli. Physiol. Plant 35:175-180.

19. Pan, C. L. 1936. A preliminary report of varietal differences in rapidity of germination in rice. J. Am. Soc. Agron. 28:985-989.

20. Ramiah, K., and Rao, M. B. V. N. 1953. Rice breeding and genetics. Indian Counc. Agric. Res. Monogr. 19.

21. Robbs, P. G., Bartz, J. A., Brecht, J. K., and 
Sargent, S. A. 1995. Oxidation-reduction potential of chlorine solutions and their toxicity to Erwinia carotovora subsp. carotovora and Geotrichum candidum. Plant Dis. 79:158-162.

22. Sauer, D. B., and Burroughs, R. 1986. Disinfection of seed surfaces with sodium hypo- chlorite. Phytopathology 76:745-749.

23. Segall, R. H. 1968. Fungicidal effectiveness of chlorine as influenced by concentration, temperature, $\mathrm{pH}$, and spore exposure time. Phytopathology 58:1412-1414.

24. Steel, R. G., and Torrie, J. H. 1980. Principles and Procedures of Statistics, A Biometrical Approach. McGraw-Hill, New York.

25. Whitam, K., Hollier, C. A., and Overstreet, C. 1990. 1990 Louisiana Plant Disease Control Guide, Pub. 1802. Louisiana State University Agricultural Center, Baton Rouge. 